\title{
Private Colleges' Teachers Use Modern Education Technology to Promote the Rapid Development
}

\author{
Xuexiao Feng ${ }^{1, a}$
}

\author{
Zhengzhou University of Industrial Technology, the School of Information Engineering, Henan, \\ China, 451100 \\ ${ }^{a}$ email,
}

Keywords: Private Colleges, University Teachers, Modern Education Technology

\begin{abstract}
From the perspective of the development of Chinese private colleges, after the analysis of the modern education technology into the teaching of the impact of the traditional teaching mode, this paper discusses the teaching model in order to adapt to the modern teachers should adopt some countermeasures: the teacher wants to receive life-long education; Break "cramming education" of the old teaching model, adopting the heuristic teaching; Teaching experiment, summarizes the teaching patterns; The teacher must complete the role transformation; Improve teachers' own quality. In modern education, teachers should according to various changes, reasonably adjust their role in the teaching, new teaching methods should be gradually improved, and enrich the teaching content, make teaching process more harmony.
\end{abstract}

\section{Quote:}

Modern technology of education put into the teaching system, the traditional teaching-mode gradually broken. With computer technology as the core of modern education technology applied to teaching, brings the education idea, education content, education method, education method, education mode, a profound revolution in the process of education. Process of teaching, teaching content, teaching method, teacher's role and student status will produce certain effect: (1) the traditional teaching process is made up of teachers, students and teaching contents of three basic elements, the modern teaching process and increase the teaching media elements; (2) to make the teaching content from a single descriptive words and graphs, charts, added into a collection of text, sound, image, animation, video in the integration of multimedia information; (3) multimedia technology applied in the teaching process, to promote the development of the teaching method to the integrated direction, make it flexible and varied teaching method; (4) in modern education, teachers are no longer as a knowledge authority of instilling knowledge to students, teachers' role will be mainly reflects in guiding students to effective learning; (5) in the traditional teaching, the students rely on the teacher's organization arrangement and requirement of learning, is passive learners. The modern teaching media as an important factor in the process of teaching, changes the student to teacher's dependence. Teachers in the multimedia teaching, therefore, should be based on the change of teaching methods, teaching contents, teaching process, constantly adjust their role in the teaching reasonably, gradually perfect the new teaching methods, and enrich the teaching content, the teaching process more harmonious unification, teachers should explore how to adapt to the modern education technology and development.

\section{College Teachers Should Accept the Lifelong Education}

In the face of the development of science and technology changes with each passing day, the teacher education, education is no longer a stage, but a lifelong education. Lifelong education's goal 
is to train the ability of independent learning, can make full use of various learning resources for lifelong learning. They can according to their own needs to constantly adjust their own knowledge structure, constantly to acquire new information, new knowledge, to improve the ability of their own survival and development, the new situation to adapt to the fast-changing society. In 1809, john Wolfgang Avon Goethe once said: "in the future do not have any thing to learn and a lifetime to enjoy. We have to learn new knowledge every five years, don't go out of time." In today's rapid development of science and technology, this sentence has already been verified. Application of modern education technology and information of the total increase of knowledge, students are required to have higher learning ability and better way of learning. Pure knowledge content way of education is no longer suitable for modern society, and to teach students how to learn. As "learn to survive", points out, "the future of illiteracy is no longer the illiterate person, but to people who don't have to learn how to study paper format." Visible "will learn" is more important than the "society". Only lifelong learning, learning to learn only lifelong learning can constantly update knowledge, and constantly to acquire new information, constantly adjust their own knowledge structure to adapt to the development of The Times. Teachers as teaching software designers, producers, the researchers of teaching work, not only to guide and help students to master the ability of lifelong learning, at the same time the teachers also should undertake lifelong learning, constantly update and broaden their knowledge. Person's life will be spent in the process of learning, "never too old to learn", is characteristic of today's society. Educators must first accept education, to complete the mission of the era have entrusted to. Teachers should be in line with lack what fill what principle for self-study or take part in the training, constantly add new knowledge, renew the idea, to master new technology, to adapt to the needs of the development of education undertakings in the new situation.

\section{Break "Cramming Education" of the Old Teaching Mode, Adopt Heuristic Teaching}

Teachers should make full use of modern multimedia teaching equipment, cultivate students' creative thinking, enhance their analysis problem, problem-solving and hands-on ability, attention to the body of the students, guide students to actively participate in, to cultivate students to explore the spirit of knowledge. Wanted to break with all the old teaching model of "cramming education", adopt heuristic teaching. At present, is vigorously advocating quality-oriented education, it puts forward new requirements for teaching methods, namely how to solve the problem of "teaching". "Spoon-feeding" method of teaching is no longer adapt to the development of teaching. To completely abandon the knowledge of old ideas, set up is given priority to with ability of new ideas. Firmly rejected hinder the development of students' innovation spirit and innovation ability education ideas and modes of education, especially the one-way infusion of knowledge by teachers too uniform and inflexible teaching methods. Teaching activities should be focusing on organizing and guiding the students' independent learning activities. To change the traditional teaching method, lets the student more independence-minded begin, getting students from "want me to learn" to "I want to learn". To carry out heuristic, the abolition of injection, the teacher must be good at to inspire ideas and principles throughout the course of classroom teaching, fully mobilize students' learning enthusiasm, initiative and creativity, in learning guidance, guides the student to the development of creative thinking, consciously cultivate students the ability and interest in learning to solve the problem. In "the Analects of Confucius" of know, well, the good person than joy of ", shows the importance of cultivating students' learning interest. For teachers, teaching is not only to teach students to learn, more important is to guide students to seek knowledge and in the vast information integration of knowledge, cultivate students' innovative consciousness and motivate the 
students' innovation spirit, exert the principal role of students, promote the quality education. USES the multimedia teaching, saved the teacher blackboard writing time, but also saved students blindly notes time, speed up the teaching schedule, teachers should consciously to set aside time "blank", let the students thinking and questioning to fully autonomous activity to fill, break them teachers, and students "q" and "speak" power, allowing students to public discussion and debate with your classmates and teacher. Fundamentally change teachers "cramming education" phenomenon.

\section{The Teaching Experiment, Summarizes the Teaching Rule}

Multimedia teaching is the use of modern education technology in teaching, therefore, to explore law of teaching in the teaching process, and by using the relevant teaching and research means and tools, collect students' feedback information in time, according to the situation and problems of the feedback of teaching contents, teaching methods, and teaching process, teaching software is modified and perfected. In the introduction of multimedia devices to realize teaching effect from economic condition, comprehensive consideration. If the number of students in class is not much, just by using the computer and projector, can not only save money, and does not affect the teaching effect. If the school is larger, the number of students in class is more, in the school under the condition of the economic conditions allow, can consider to computer plus screen device with multiple monitor configuration. Should be paid attention to in the development of multimedia course-ware, in addition to display text abstraction, extension, summarized, enrich the teaching content, also, vivid, appropriate, animation, graphic to attract students, help students grasp the teaching contents. Should also pay special attention to the screen display content must be appropriate, content measurement should be able to control the thinking ways of students and teachers. According to the background and the user interface design too loud, lest a presumptuous guest usurps the host's role. Design at the same time also pay attention to the speed of the animation, do not show too fast, nor too slow. Fast couldn't keep up with students, slowly will turn the line of sight of students to other places. In the process of multimedia teaching, teachers have to be very familiar with the content of teaching; can watch lesson plans and display can be taught. So that teachers can have time and energy to adjust the classroom atmosphere. In addition, although be in multimedia classroom teaching, but the existing CAI system only students overwhelmed to see teacher demonstration, but not in time practice, thus a lot of knowledge can not be, a little impression, forgotten faster, but we can in a campus online multimedia software, students can on any computer is connected to the Internet is not restricted by time and place, use the discrete time in class in your review, can even do diy experiment, problem sets, consolidate what they have learned in class. To make the students study interest and subjective initiative into full play.

\section{The Teacher Must Prepare for Transition}

With the development of multimedia education technology, teachers' role in such aspects as its characteristics, the function will change. Teachers are no longer students obtain knowledge the only source of information, the authority of teachers will also gradually lost consciousness. The change of teacher role, is not to say that modern education technology make the teacher lost the status of the "master" the role of degradation, but with higher requirement for teachers' role. The new role makes the function of teachers more diversified. Teachers need knowledge discriminator, organizers and administrators of teaching process, the role of the precept, as an example to the students did not change, and should play better. Teachers not only teaching, professional love life, a teacher by worthy example, also should have broad thick business knowledge. Multimedia teaching requires 
teachers should not only have rich knowledge, but also familiar with modern multimedia technology, use, operation skills. Requires teachers to design the teaching in class, the content of teaching, a targeted select teaching media, design the best teaching plan, so that the students in the shortest possible time to accept and grasp the most amount of information, help students to open the door to grasp the new paper format learning method. Multimedia teaching requires teachers from pure mainly impart knowledge to give priority to in order to design the teaching, from teaching to inspire the helper, students are required to shift from pure passively accepting knowledge for self study, self discovery, teaching students is no longer a passive, but active participants in the teaching process. Teachers should gradually must transform their role from indoctrinating knowledge learning ability for the students of the guide. The application of modern education technology and the increase of the total information technology, students are required to have higher learning strategies and learning ability, teachers should strengthen the guide of students learning methods. As the saying goes: "to give a person a fish is better than a fish. To make the students gradually from passive knowledge receiver into active knowledge explorer.

\section{Run by the Local People to Improve the Quality of Teachers in Colleges and Universities}

The development of modern education technology provides teachers with a lot of new means of imparting knowledge, especially the computer assisted instruction and multimedia technology in teaching show strong vitality and broad prospects for development. Teachers learn how to apply the teaching technology, and to explore the thought and method of multimedia teaching and set up modern teaching ideas, to adapt to the new situation of modern education. The implementation of the modern education technology not only should have modern education method, modern means of education, also must have a qualified person to complete. Teacher is the executor of the teaching activities, modern multimedia teaching to teacher put forward higher request. Teachers to apply modern education technology to teach must improve their own quality. They not only to master specialized knowledge, but also grasp using the modern technology of education, to send students knowledge quickly. This requires that teachers must update teaching ideas, get rid of traditional teaching methods, study the new teaching mode, to improve the teaching quality and teaching efficiency, developed to adapt to different teaching contents and teaching levels of multimedia course-ware. The development of multimedia course-ware is a very important and difficult work. It's not just the book characters on a computer screen, but the summary, summarized the content of the original knowledge, extension, the process of innovation. Through the combination of sound, like, figure, wen, can make complex, abstract and difficult to understand the knowledge, become image intuitive and easy to understand, easy to grasp the information, therefore, the task is very heavy. Teachers to develop their professional multimedia course-ware, the improvement of teachers' own quality is also a promotion. Colleges and universities are the base to cultivate high-level talents, the cultivation of high-level personnel cannot leave a high level of teachers. Professor teacher in addition to study their professional knowledge outside, still should keep learning the modern computer technology, computer information processing technology and knowledge of pedagogy, psychology, aesthetics, etc, constantly expanding the area of their knowledge, improve the overall quality of teaching, to adapt to the development needs of modern education in the new century. The modern education technology is an important product of the knowledge economy era, is to promote education reform, deepen the education practice, and change the teaching method is a powerful weapon, it will be more and more in the process of education, teaching play its important role. 


\section{Conclusion}

The influence of the modern education technology on education is deepening, which requires the education workers to renew the idea, not only to update the knowledge, the more truly become the pioneer of The Times, the modern human soul engineer.

\section{References}

[1] Lin Fen z hi-jun GAO. The role of the transformation of education calls for teachers update [J]. Journal of education, 2002, (1): 44-461

[2] Lou Peiping Sun Hating. The realization of the theory of college students' autonomous learning [J]. Journal of teaching research, 2002, 25 (3) : 207-2091

[3] To f, Han . The application of multimedia technology in higher education and the development trend of [J]. Journal of teaching research, 2002, 25 (2) : 149-1511

[4] young-fang, Wang yang, Angelia Mu. Use of multimedia teaching to improve teaching quality of study [J]. Journal of continuing education research, 2002, (2) : 881

[5] Xiaoping. Under the lifelong education idea of higher education reform and development [J]. Journal of Chongqing institute of post and telecommunications (social science edition), 2001, (3): 53-561 